\title{
Role of delta opioid efficacy as a determinant of mu/delta opioid interactions in rhesus monkeys
}

\author{
S. Stevens Negus, Ashley E. Bear, John E. Folk, and Kenner C. Rice \\ Alcohol and Drug Abuse Research Center; McLean Hospital-Harvard Medical School, Belmont, \\ MA (SSN, AEB); Dept. of Pharmacology and Toxicology, Virginia Commonwealth University, \\ Richmond VA (SSN); and Chemical Biology Research Branch, National Institute on Drug Abuse \\ and National Institute on Alcohol Abuse and Alcoholism, National Institutes of Health, DHHS, \\ Bethesda, MD (JEF, KCR)
}

\begin{abstract}
Delta opioid agonists can selectively enhance the antinociceptive effects of mu opioid agonists without enhancing some other, potentially undesirable mu agonist effects. However, the degree of delta receptor efficacy required to produce this profile of interactions is unknown. To address this issue, the present study examined interactions produced by the mu agonist fentanyl and the intermediate-efficacy delta opioid MSF61 in rhesus monkeys. For comparison, interactions were also examined between fentanyl and the relatively high-efficacy delta agonist SNC243A and the delta antagonist naltrindole, which has neglible efficacy at delta receptors. Two different behavioral procedures were used: (a) a warm-water tail-withdrawal assay of thermal nociception, and (b) an assay of schedule-controlled responding for food reinforcement. Drug interactions within each procedure were evaluated using dose-addition analysis to compare experimental results with expected additivity. Drug interactions across procedures were evaluated using dose-ratio analysis to assess relative potencies to produce antinociception vs. response-rate suppression. As expected, doseaddition analysis found that fentanyl/SNC243A interactions were superadditive in the assay of antinociception but additive in the assay of schedule-controlled responding. Conversely, fentanyl/ MSF61 interactions were generally additive in both procedures, and fentanyl/naltrindole interactions were additive or subadditive in both procedures. Dose-ratio analysis found that fentanyl alone produced antinociception and rate suppression with similar potencies. Some fentanyl/SNC243A mixtures produced antinociception with up to 4-fold greater potency than rate-suppression. However, fentanyl/MSF61 and fentanyl/naltrindole mixtures produced antinociception with lower potency than rate suppression. These results suggest that relatively high delta receptor efficacy is required for mu/ delta antinociceptive synergy.
\end{abstract}

\section{Index Words}

delta opioid receptor; mu opioid receptor; interaction; antinociception; efficacy; rhesus monkey

Corresponding Author: S. Stevens Negus, Dept. of Pharmacology and Toxicology, Virginia Commonwealth University, 410 N. 12 th Street, PO Box 980613, Richmond, VA 23298, Phone: (804)828-3158, FAX: (804)828-2117, Email: E-mail: ssnegus@ vcu.edu.

Publisher's Disclaimer: This is a PDF file of an unedited manuscript that has been accepted for publication. As a service to our customers we are providing this early version of the manuscript. The manuscript will undergo copyediting, typesetting, and review of the resulting proof before it is published in its final citable form. Please note that during the production process errors may be discovered which could affect the content, and all legal disclaimers that apply to the journal pertain. 


\section{Introduction}

Opioid drugs produce their effects by acting at three types of receptors, the mu, delta and kappa opioid receptors (Kieffer, 1995; Lord et al., 1977; Martin et al., 1976). Selective agonists have been developed for each receptor type, and mu, delta and kappa agonists produce distinct profiles of physiological and behavioral effects in rhesus monkeys and other species (Dykstra et al., 1988; Gutstein and Akil, 2005; Negus et al., 1998b; Woods et al., 1982). Although selective mu opioid agonists remain extremely valuable as analgesics for the treatment of strong pain, their clinical utility is limited by side-effects including sedation, respiratory depression and high abuse potential. Accordingly, a goal in drug development has been to explore strategies for separating the clinically valuable analgesic effects of mu agonists from their undesirable effects. One strategy for achieving this goal has been suggested by the finding that different types of opioid receptors may interact to modulate the effects of agonists acting at those receptors (Rothman and Xu, 2004). For example, mixtures of selective mu and delta agonists have been found to produce additive or synergistic antinociceptive effects in both rodents and non-human primates (Adams et al., 1993; Dykstra et al., 2002; Heyman et al., 1989b; Stevenson et al., 2003; Vaught and Takemori, 1979). In contrast, mu and delta agonists do not enhance most of each other's non-antinociceptive effects, and in some cases, they attenuate each other's effects. In rats, for example, combinations of the mu agonist alfentanil and the delta agonist BW373U86 \{( \pm$)-4-[(\alpha \mathrm{R})-\alpha-(2 \mathrm{~S}, 5 \mathrm{R})-4$-allyl-2,5-dimethyl-1piperazinyl-3-hydroxybenzyl]-N,N-diethylbenzamide $\}$ produced additive antinociceptive effects, but the combinations produced less respiratory depression than alfentanil alone and fewer convulsions than BW373U86 alone (Su et al., 1998). In rhesus monkeys, the delta agonist SNC80 \{(+)-4-[( $\alpha \mathrm{R})-\alpha-((2 \mathrm{~S}, 5 \mathrm{R})-4$-allyl-2,5-dimethyl-1-piperazinyl)-3-methoxybenzyl]$\mathrm{N}, \mathrm{N}$-diethylbenzamide $\}$ enhanced the antinociceptive effects of several mu agonists, but it did not enhance either their sedative effects in an assay of schedule-controlled responding for food reinforcement or their abuse-related reinforcing effects in assays of drug self-administration (Stevenson et al., 2005; Stevenson et al., 2003). Taken together, these findings suggest that simultaneous activation of both mu and delta opioid receptors may produce strong analgesia with fewer side effects than selective activation of mu opioid receptors alone.

Although the general principle of positive antinociceptive interactions between mu and delta opioids has been well-established, the precise pharmacological determinants of mu/delta interactions remain to be clarified. For example, one factor that may influence mu/delta interactions is the efficacy of the component drugs at their respective receptor targets. We reported previously that the high-efficacy delta agonist SNC80 produced synergistic antinociceptive effects in combination with mu opioids that display high, intermediate and low efficacy at mu opioid receptors (methadone, fentanyl, heroin, morphine, nalbuphine) (Stevenson et al., 2005; Stevenson et al., 2003). This suggests that mu agonists with a broad range of efficacies can contribute to mu/delta antinociceptive synergy in non-human primates. Efficacy requirements at the delta receptor for mu/delta antinociceptive synergy have not been systematically examined. However, both behavioral studies in rodents and in vitro functional assays suggest that high delta efficacy may not be required. For example, synergistic antinociceptive effects were observed in mice between some mu agonists and the peptidic delta opioid DPDPE (Heyman et al., 1989b), which has submaximal efficacy at delta receptors as determined from assays of agonist-stimulated GTPgS binding (Clark et al., 1997; Jutkiewicz et al., 2004).

The primary purpose of the present study was to evaluate the ability of an intermediate-efficacy delta opioid to enhance the antinociceptive effects of the mu agonist fentanyl in rhesus

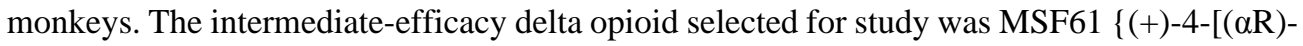
$\alpha$-(2S,5R)-4-cyclopropylmethyl-2,5-dimethyl-1-piperazinyl-3-methoxybenzyl]-N,Ndiethylbenzamide\}. This compound was evaluated for three reasons. First, it is an N- 
cyclopropylmethyl derivative of the high-efficacy delta agonist SNC80, which we have shown previously to produce antinociceptive synergy in combination with fentanyl (Stevenson et al., 2003). Second, MSF61 binds with nanomolar affinity and $\geq 300$-fold selectivity to delta receptors vs. mu and kappa opioid receptors (see compound 3i in (Furness et al., 2000). Lastly, MSF61 displayed intermediate efficacy at delta receptors in an assay of agonist-stimulated GTPgS binding, where it functioned as a partial agonist and produced approximately $38 \%$ of the maximal effect defined by the full agonist SNC80 (Furness et al., 2000). This is similar to or slightly lower than the efficacy of the prototype peptidic delta opioid DPDPE (45-60\% of the maximal stimulation produced by SNC80 or BW373U86 (Clark et al., 1997; Jutkiewicz et al., 2005). In the present study, MSF61 was evaluated for both its delta agonist and delta antagonist effects in vivo, as well as for its interactions with fentanyl.

As in our previous studies of mu/delta, mu/kappa and delta/kappa opioid interactions in rhesus monkeys (Negus et al., 2008; Stevenson et al., 2005; Stevenson et al., 2003), the interactions between MSF61 and fentanyl were evaluated in both an assay of thermal nociception and an assay of schedule-controlled responding maintained by food reinforcement. The assay of thermal nociception was used to provide information on a preclinical experimental endpoint related to the principal therapeutic effect of opioids (i.e. analgesia). The assay of schedulecontrolled responding, which has been used extensively in research on the behavioral pharmacology of opioids (e.g. (Negus et al., 1993), was used to provide comparative data on the behavioral depressant/sedative effects of opioids unrelated to pain and analgesia. Interactions between fentanyl and MSF61 were compared to interactions between fentanyl and (a) the selective, high-efficacy delta opioid SNC243A \{(+)-4-[(aR)-a-(2S,5R)-4-allyl-2,5dimethyl-1-piperazinyl-3-fluorobenzyl]-N,N-diethylbenzamide (Calderon et al., 1997; Negus et al., 1998b), and (b) the selective, low-efficacy delta opioid naltrindole (Negus et al., 1994; Portoghese et al., 1988).

\section{Methods}

\subsection{Subjects}

Five adult male rhesus monkeys (Macaca mulatta) were used in studies of schedule-controlled responding, and three adult male and two adult female monkeys were used in studies of thermal nociception. Subjects weighed 4.6-12.4 kg during the course of these studies. All monkeys had prior exposure to drugs (primarily dopaminergic and opioid compounds) and to the behavioral procedures in which they were tested. The subjects were individually housed, and water was freely available. Their diet consisted of PMI Feeds Jumbo monkey diet (2-6 biscuits/day delivered after experimental sessions; PMI Feeds, Inc., St. Louis, MO) supplemented with fresh fruit twice daily. In addition, monkeys in the assay of schedule-controlled behavior could earn additional food pellets during experimental sessions. A $12 \mathrm{~h}$ light/12 h dark cycle was in effect (lights on from 7AM-7PM).

Animal maintenance and research were conducted in accordance with the guidelines provided by the NIH Committee on Laboratory Animal Resources. The facility was licensed by the United States Department of Agriculture, and protocols were approved by the Institutional Animal Care and Use Committee. The health of the monkeys was monitored daily by the staff veterinarian. Monkeys had visual, auditory and olfactory contact with other monkeys throughout the study. Monkeys also had access to puzzle feeders, mirrors and chew toys to provide environmental enrichment. Nature videotapes or music were played daily in all housing rooms. 


\subsection{Behavioral and Pharmacological Procedures}

Behavioral studies were conducted using two procedures: (1) an assay of schedule-controlled responding for food presentation, and (2) an assay of thermal nociception using warm water as the noxious stimulus. These procedures have been used extensively by our laboratory to examine the effects of other opioids and of delta/mu interactions in rhesus monkeys (Negus et al., 2008; Stevenson et al., 2005; Stevenson et al., 2003). In each assay, the effects of the mu agonist fentanyl were studied alone or in combination with the delta opioids SNC243A, MSF61 and naltrindole. Both in vivo and in vitro data suggest that fentanyl is a selective and relatively high efficacy agonist at mu opioid receptors (Emmerson et al., 1996; Emmerson et al., 1994; Negus, 2002; Negus et al., 1993). SNC243A and MSF61 are selective arylacetamide delta opioid receptor ligands structurally related to SNC80, and naltrindole is a selective delta receptor antagonist (see Introduction). Fentanyl, arylacetamide delta opioids and naltrindole have similar rapid onsets of action (peak effects in $\sim 15 \mathrm{~min}$ ) and durations of action that vary from 1-2 $\mathrm{h}$ for fentanyl and arylacetamide delta opioids to $\sim 4 \mathrm{~h}$ for naltrindole (Brandt et al., 2001; Negus et al., 1994; Negus et al., 1998a; Negus et al., 1998b).

2.2.1. Assay of Schedule-Controlled Responding-Experiments were conducted in each monkey's home cage (dimensions: $60 \times 65 \times 75 \mathrm{~cm}$ ). The home cages of all monkeys were modified to include an operant response panel $(28 \times 28 \mathrm{~cm})$ mounted on the front wall. Three square translucent response keys $(6.4 \times 6.4 \mathrm{~cm})$ were arranged $2.54 \mathrm{~cm}$ apart in a horizontal row $3.2 \mathrm{~cm}$ from the top of the operant panel. Each key could be transilluminated by red, green or yellow stimulus lights. The operant panel also supported an externally-mounted pellet dispenser (Gerbrands, Model G5210; Arlington, MA) that delivered $1 \mathrm{gm}$ bananaflavored food pellets (Purina Test Diet, Richmond, IN) to a food receptacle mounted on the cage beneath the operant response panel. The panel was controlled by a MED-PC interface and an IBM compatible computer programmed in MEDSTATE Notation (MED Associates, Inc., East Fairfield, VT).

Experiments used a multiple-cycle procedure. Each of 5 cycles was 15 min long and consisted of two components: a 10-min timeout period followed by a 5-min response period. During the timeout period, no stimulus lights were illuminated and responding had no scheduled consequences. During the response period, the center key was transilluminated yellow, and the subjects could respond for up to 10 food pellets under a fixed-ratio 30 (FR30) schedule of reinforcement. If all 10 food pellets were earned before $5 \mathrm{~min}$ had elapsed, the lights were turned off, and responding had no scheduled consequences for the remainder of that response period. All monkeys were trained until they responded at rates greater than 1.0 response/s during all five cycles for 10 consecutive days, and we have shown previously that monkeys respond at relatively stable rates across successive response periods in this procedure (Negus et al., 1993a).

Sessions were conducted 5 days a week. Test sessions were usually conducted on Tuesdays and Fridays, and training sessions were conducted on Mondays, Wednesdays and Thursdays. In addition, test sessions were conducted only after a training session during which the monkeys responded at rates greater than 1.0 response/s for all five cycles. Test sessions were identical to training sessions except that test compounds were administered using a cumulative dosing procedure, in which doses of the test drug or drug mixture were administered at the beginning of each timeout period, and each dose increased the total cumulative dose by $1 / 4$ or $1 / 2 \log$ units.

Initially, complete dose-effect curves were determined for fentanyl $(0.001-0.1 \mathrm{mg} / \mathrm{kg})$, SNC243A (0.032-0.32 mg/kg), MSF61 $(1.8-10 \mathrm{mg} / \mathrm{kg})$ and naltrindole $(1.0-10 \mathrm{mg} / \mathrm{kg})$ administered alone, and each drug was tested twice. Neither MSF61 nor naltrindole reliably suppressed rates in this procedure across the dose range tested. As a result, MSF61 (10 mg/kg) 
was tested for its ability to antagonize the rate-decreasing effects of the delta agonist SNC80 $(0.1-32 \mathrm{mg} / \mathrm{kg})$.

Subsequently, three mixtures of fentanyl in combination with each delta opioid were examined. For mixtures of SNC243A + fentanyl, the proportions of the drugs in the mixtures were determined by their relative potencies to decrease response rates. Relative potency (RP) was defined as ED50 SNC243A $\div$ ED50 fentanyl, and the proportions of SNC243A to fentanyl in the three mixtures were RP $\div 3$, RP, and RPx3. For mixtures of either MSF61 + fentanyl or naltrindole + fentanyl, the proportions of the drugs in the mixtures were determined by the relative potency of MSF61 and naltrindole to produce delta antagonist effects (expressed as the $\mathrm{mg} / \mathrm{kg}$ conversion of $\mathrm{pKB}$ or $\mathrm{pA} 2$ values; i.e. the dose required to produce $50 \%$ receptor occupancy) in comparison to the potency of fentanyl to produce mu agonist effects (expressed as fentanyl ED50). Thus, RP was defined as pKB or pA2 for MSF61 or naltrindole (in $\mathrm{mg} / \mathrm{kg}$ ) $\div$ ED50 fentanyl, and proportions of MSF61 and naltrindole in the mixtures were $\mathrm{RP} \div 3$, RP, and RPx3. Each mixture was tested once. All tests were separated by at least one week.

2.2.2. Assay of Thermal Nociception-Monkeys were seated in acrylic restraint chairs so that their tails hung down freely. The bottom $10 \mathrm{~cm}$ of each monkey's shaved tail was immersed in a thermal container of warm water. If the subject did not withdraw its tail within $20 \mathrm{~s}$, the tail was removed from the water by the experimenter, and a latency of $20 \mathrm{~s}$ was assigned to that measurement. During each cycle of measurements, tail-withdrawal latencies were measured from water heated to 38 and $50^{\circ} \mathrm{C}$. The order in which the temperatures were presented varied from one set of measurements to the next. Experiments were conducted no more than twice a week. A stopwatch was used to measure and record time intervals.

Each test session consisted of multiple 30 min cycles. Before the first cycle, baseline latencies to tail-withdrawal from 38 and $50^{\circ} \mathrm{C}$ water were determined. Testing continued only if tail withdrawal from $38^{\circ} \mathrm{C}$ water did not occur before the $20 \mathrm{~s}$ cutoff, and if tail withdrawal occurred in $\leq 3 \mathrm{~s}$ from $50^{\circ} \mathrm{C}$ water. This criterion was met during every session with every monkey in this study. During cumulative dosing experiments, a single drug dose was administered at the start of each of five sequential $30 \mathrm{~min}$ cycles, and each dose increased the total cumulative dose by $1 / 4$ or $1 / 2 \log$ units. Starting 20 minutes after each injection, tail-withdrawal latencies were recorded as described above. Initially, complete dose-effect curves were determined for fentanyl (0.001-0.1 mg/kg), SNC243A (0.032-3.2 mg/kg), MSF61 (1.8-10 mg/kg) and naltrindole $(1.0-10 \mathrm{mg} / \mathrm{kg})$ alone. Subsequently, three mixtures of fentanyl in combination with each delta opioid were examined, and the proportions of each drug in the mixtures were identical to those examined in the assay of schedule-controlled behavior described above. Each drug mixture was tested once. All tests were separated by at least one week.

\subsection{Data Analysis}

2.3.1. Dose-Effect Curve Analysis-For the assay of schedule-controlled responding, operant response rates from each cycle were converted to percent of control using the average rate from the previous training day as the control value. The ED50 for each drug was defined as the dose that reduced response rates to 50 percent of the control rate of responding. Individual ED50s were calculated by interpolation when only two data points were available (one below and one above $50 \%$ control response rate) or by linear regression when at least three data points were available on the linear portion of the dose-effect curve. For drug mixtures, ED50 values were defined as the dose of each drug in the mixture that reduced response rates to $50 \%$ of control. In addition, a related quantity, Zmix, was also calculated for each monkey as the total drug dose that reduced response rates to 50\% of control (i.e. ED50 for fentanyl + ED50 for other drug in mixture). 
For the assay of thermal nociception, drug effects were expressed as \%Maximum Possible Effect (\%MPE) using the following equation:

$\%$ MPE $=($ Test Latency - Control Latency $) /(20-$ Control Latency $) * 100$

where test latency was the tail withdrawal latency from $50^{\circ} \mathrm{C}$ water obtained after drug administration, and control latency was the latency obtained at the beginning of the session prior to drug administration. ED50 and Zmix for each drug or drug mixture were defined as the dose(s) that produced 50\%MPE, and these values were determined by interpolation or linear regression as defined above. For both the schedule-controlled responding and thermal nociception procedures, individual ED50 and Zmix values were averaged to determine mean values and $95 \%$ confidence limits, and values were considered to be significantly different if confidence limits did not overlap.

For studies to evaluate MSF61 antagonism of the delta agonist SNC80, the dose of MSF61 required to produce a 2-fold rightward shift in the SNC80 dose-effect curve was determined using pKB analysis (Negus et al., 1993) according to the equation $\mathrm{pKB}=-\log [\mathrm{B} /(\mathrm{DR}-1)]$, where B equals the dose of MSF61 in moles $/ \mathrm{kg}$, and DR (Dose Ratio) $=$ ED50 for agonist after antagonist treatment $\div$ ED50 for agonist alone. The pKB was converted back to units of $\mathrm{mg} /$ $\mathrm{kg}$ to permit calculation of mixture proportions as described above. The $\mathrm{pA} 2$ value for naltrindole as a delta antagonist in rhesus monkeys was determined previously to be 6.3 (Negus et al., 1994), which is equivalent to a dose of $0.23 \mathrm{mg} / \mathrm{kg}$.

2.3.2. Dose-Addition Analysis-Drug interactions were evaluated both within and across assays. Drug interactions within a given assay were assessed using both graphical and statistical approaches to dose-addition analysis (Tallarida, 2000; Wessinger, 1986; Woolverton, 1987) as described previously (Stevenson et al., 2005; Stevenson et al., 2003). Graphically, data for each drug and drug mixture were plotted as isobolograms. Statistical evaluation of drug interactions was accomplished by comparing the experimentally determined ED50 values for each mixture (Zmix) with predicted additive ED50 values (Zadd) as described by Tallarida (Tallarida, 2000). Zmix values were determined empirically as described above. When mixtures were studied in an assay where each drug alone was also active (i.e. fentanyl with SNC243A in the assay of schedule-controlled responding), Zadd values were calculated individually for each monkey from the equation Zadd $=f A+(1-f) B$, where $A$ was the ED50 for fentanyl alone, $B$ was the ED50 for the other drug alone, and $f$ was the fractional multiplier of $A$ in the computation of the additive total dose. Any choice of $f$ is related to the proportion of $\operatorname{drug} A(\mathrm{r} A)$ in a mixture according to the equation $\mathrm{r}_{\mathrm{A}}=f A /$ Zadd. When mixtures were studied in an assay where only one drug was active, the hypothesis of additivity predicts that the inactive drug should not contribute to the effects of a mixture. As a result, the equation for Zadd reduces to Zadd $=A / \mathrm{r}_{\mathrm{A}}$. Mean Zmix and Zadd values were considered to be significantly different if 95\% confidence limits did not overlap.

2.3.3. Dose-Ratio Analysis-To evaluate drug interactions across assays, the relative potency of each drug and drug mixture in the two behavioral procedures was quantified using dose-ratio analysis as described previously (Negus et al., 2008). Specifically, the Dose Ratio (DR) for each drug or drug mixture was defined as the ratio of the ED50 (or Zmix) in the assay of schedule-controlled responding $\div$ ED50 (or Zmix) in the assay of thermal nociception. Thus, if a drug or drug mixture was equipotent in the two procedures, then ED50 in the assay of schedule-controlled responding would be equal to the ED50 (or Zmix) in the assay of thermal nociception, and $\mathrm{DR}=1$. DR $>1$ indicates that the drug or drug mixture was more potent in the assay of thermal nociception. Conversely, $\mathrm{DR}<1$ indicates that the drug or drug mixture was 
more potent in the assay of schedule-controlled responding. The potency of each drug or drug mixture was considered to be different across the two procedures if the $95 \%$ confidence limits of the ED50 or Zmix values in the two procedures did not overlap.

\section{4. Drugs}

SNC80, SNC243A and MSF61 (all free bases) and naltrindole $\mathrm{HCl}$ were synthesized by Drs. Kenner C. Rice and John E. Folk (National Institutes of Health, Bethesda, MD). Fentanyl HCl was provided by the National Institute on Drug Abuse (Bethesda, MD). SNC80, SNC243A, MSF61 were dissolved in 2-3\% lactic acid to a final concentration of $50 \mathrm{mg} / \mathrm{ml}$, and dilutions were made with sterile water. Naltrindole and fentanyl were dissolved in sterile water. All drugs were administered i.m. in the thigh, and doses were determined based on the free base or salt forms listed above.

\section{Results}

\subsection{Assay of Schedule-Controlled Responding}

3.1.1. Control response rates and effects of opioid agonists alone-The average control response rate $( \pm$ S.E.M.), determined on the days before test days throughout the study, was $2.38( \pm 0.50)$ responses/s. Response rates were similar during each of the five cycles of the multiple cycle sessions $(2.45 \pm 0.54,2.34 \pm 0.53,2.40 \pm 0.46,2.35 \pm 0.49,2.36 \pm 0.47$ responses/s).

Figures 1 shows the dose-effect curves for fentanyl and each of the delta receptor ligands administered alone. Fentanyl and the high-efficacy delta agonist SNC243A produced dosedependent decreases in response rates, and ED50 values are shown in Table 1. The intermediate-efficacy delta opioid MSF61 and the delta antagonist naltrindole at doses up to $10 \mathrm{mg} / \mathrm{kg}$ did not reliably alter response rates, and ED50 values could not be determined.

MSF61 was further evaluated to determine whether it functioned as a delta antagonist in this procedure. Pretreatment with $10 \mathrm{mg} / \mathrm{kg}$ MSF61 produced a significant, 7-fold increase in the ED50 for the high-efficacy delta agonist SNC80 [ED50 (95\%CL) for SNC80 alone $=2.05 \mathrm{mg}$ / $\mathrm{kg}(0.82-5.15)$; ED50 (95\% CL) for SNC80 after pretreatment with $10 \mathrm{mg} / \mathrm{kg}$ MSF61 = 14.29 $\mathrm{mg} / \mathrm{kg}$ (5.30-38.54)]. The pKB value for this delta antagonist effect of MSF61 was 5.44, which is equivalent to a dose of $1.70 \mathrm{mg} / \mathrm{kg}$.

Relative potency values were determined using the agonist ED50 values for fentanyl ( 0.023 and $0.019 \mathrm{mg} / \mathrm{kg}$, depending on the group of animals used) and SNC243A $(0.35 \mathrm{mg} / \mathrm{kg})$, and the antagonist pKB or pA2 values for MSF61 $(1.70 \mathrm{mg} / \mathrm{kg})$ and naltrindole $(0.23 \mathrm{mg} / \mathrm{kg})$. Thus relative potencies for each delta ligand in comparison to fentanyl were 15:1 for SNC243A/ fentanyl, 89:1 for MSF61/fentanyl, and 12:1 for naltrindole/fentanyl. These relative potencies were then used to determine proportions of delta ligands and fentanyl in drug mixtures.

3.1.2. Effects of fentanyl in combination with delta ligands-Figure 2 (top panels) shows the dose-effect curves for fentanyl administered alone and in combination with different proportions of each delta ligand. Isobolograms are shown in the bottom panels of Figure 2. Table 1 shows ED50 values for each drug in each mixture, and Table 2 shows the predicted Zadd values and empirically determined Zmix values for each drug mixture. In general, ED50s for all drugs in combination were lower than ED50s for the drugs administered alone, and in some cases, these differences reached statistical significance (Table 1). For example, the ED50 values for fentanyl and MSF61 in the 89:1 mixture were both significantly lower than the ED50s for each drug alone. However, with only two exceptions, all drug combinations produced effects consistent with additivity (i.e. Zadd was not significantly different from Zmix; Table 2). One exception was that the 89:1 MSF61/fentanyl mixture produced a superadditive 
effect. The other exception occurred with fentanyl in combination with the highest proportion of naltrindole (36:1 naltrindole/fentanyl). This mixture did not decrease response rates below $50 \%$ of control at doses up to $0.056 \mathrm{mg} / \mathrm{kg}$ fentanyl $+2.02 \mathrm{mg} / \mathrm{kg}$ naltrindole. The drug interaction was subadditive and suggestive of antagonism.

\subsection{Assay of Thermal Nociception}

3.2.1. Baseline T10 values and effects of opioid agonists alone-Under baseline conditions, monkeys never withdrew their tails from water heated to $38^{\circ} \mathrm{C}$, and they rapidly withdrew their tails from water heated to $50^{\circ} \mathrm{C}$. Over the course of the study, the mean \pm S.E.M. tail withdrawal latency from $50^{\circ} \mathrm{C}$ water was $0.86 \pm 0.10 \mathrm{~s}$.

Figures 3 shows the dose-effect curves for fentanyl and each of the delta receptor ligands administered alone. Only fentanyl produced a dose-dependent antinociceptive effect, and the ED50 values for fentanyl in the different groups of monkeys are shown in Table 3. None of the delta ligands produced antinociception up to the highest doses tested $(10 \mathrm{mg} / \mathrm{kg})$. Higher doses of SNC243A were not tested to avoid possible undesirable effects such as convulsions (Danielsson et al., 2006; Negus et al., 1994; Negus et al., 1998b). Higher doses of MSF61 and naltrindole were not tested, because MSF61 (see above) and naltrindole (Negus et al., 1994) produce delta antagonist effects at these or lower doses.

3.2.2. Effects of fentanyl in combination with delta ligands-Figure 4 (top panels) shows the dose-effect curves for fentanyl administered alone and in combination with different proportions of each delta ligand. Isobolograms are shown in the bottom panels of Figure 4. Table 3 shows ED50 values for each drug in each mixture, and Table 4 shows the predicted Zadd values and empirically determined Zmix values for each drug mixture. All mixtures of fentanyl with the delta agonist SNC243A produced superadditive antinociceptive effects. For all mixtures, the ED50 values for fentanyl and SNC243A in the mixtures were significantly lower than the ED50 values for either drug alone (Table 3). Moreover, for all mixtures, the empirically determined Zmix values were significantly lower than the predicted Zadd values (Table 4). Graphically, these effects were manifested as leftward shifts in the fentanyl doseeffect curve (Figure 4 top left panel). In addition, drug-mixture points were located to the left of the dose-additivity line in the isobologram (Figure 4 bottom left panel). In contrast to the consistent superadditive effects obtained with fentanyl/SNC243A combinations, mixtures of fentanyl and MSF61 produced only additive effects. Mixtures of fentanyl and naltrindole tended to produce subadditive effects, and this subadditivity was significant for the $4: 1$ and 36:1 mixtures.

\subsection{Dose-Ratio Analysis}

Figure 5 shows dose ratios for the potency of each drug and drug mixture to decrease rates of schedule-controlled responding and to produce thermal antinociception. Fentanyl alone was roughly equipotent in producing these two effects, and the dose of fentanyl that produced full antinociception $(0.032 \mathrm{mg} / \mathrm{kg})$ also produced relatively large decreases in rates of food-

maintained responding. Dose ratios could not be calculated for the delta ligands, because none of the ligands were effective in the assay of thermal nociception.

Mixtures of fentanyl and the delta agonist SNC243A tended to produce dose ratios $>1$. This effect was significant for the 5:1 and 15:1 SNC243A/fentanyl mixtures, with both mixtures producing dose ratios at least 4-fold greater than for fentanyl alone. As one consequence of this change in relative potency, doses of 5:1 and 15:1 SNC243A/fentanyl could be administered that produced full antinociception while producing little or no effect on rates of foodmaintained responding (i.e. 5:1 and 15:1 SNC243A $+0.01 \mathrm{mg} / \mathrm{kg}$ fentanyl). The 45:1 SNC243A/fentanyl mixture produced a dose-ratio little different from fentanyl alone. Thus, 
while dose-addition analysis indicated that all SNC243A/fentanyl mixtures produced superadditive antinociceptive effects and additive effects in the assay of schedule-controlled responding, dose-ratio analysis revealed no change in the relative potency of the mixtures to produce these two behavioral effects.

Mixtures of MSF61 and fentanyl tended to produce dose ratios $<1$, and this effect was significant for the 89:1 mixture. Mixtures of 4:1 and 12:1 naltrindole/fentanyl also produced dose ratios $<1$, and a dose ratio could not be determined for the highest proportion of 36:1 naltrindole/fentanyl, because this mixture produced neither thermal antinociception nor decreases in rates of food-maintained responding across the dose-range tested.

\section{Discussion}

The main finding of the present study was that MSF61 did not have sufficient efficacy in rhesus monkeys to either (a) suppress response rates in the assay of schedule-controlled responding, or (b) enhance the antinociceptive effects of the mu agonist fentanyl. Moreover, MSF61 antagonized effects produced by the high-efficacy delta opioid SNC80. Thus, MSF61 produced delta antagonist effects in vivo similar to those produced by the low-efficacy delta opioid naltrindole and unlike the agonist effects produced by the high-efficacy delta opioid SNC243A. One implication of these results is that relatively high delta receptor efficacy is required for $\mathrm{mu} /$ delta antinociceptive synergy in rhesus monkeys.

\subsection{Interactions between fentanyl and the high-efficacy delta agonist SNC243A}

In the present study, dose-addition analysis revealed that the high efficacy delta agonist SNC243A produced superadditive interactions with fentanyl in the assay of thermal antinociception but only additive interactions in the assay of schedule-controlled responding. These differential interactions resulted in enhanced dose ratios that quantified relative potency to produce rate suppression vs. antinociception. These findings agree with previous studies from our laboratory showing that the high-efficacy delta agonist SNC80 also produced superadditive antinociceptive interactions with fentanyl and a range of other mu agonists while producing only additive or sub-additive interactions in assays of schedule-controlled responding and drug self-administration (Stevenson et al., 2005; Stevenson et al., 2003). Studies in rodents have also found that non-peptidic and peptidic delta agonists enhanced the antinociceptive effects of mu agonists to a greater degree than they enhanced most other mu agonist effects (Adams et al., 1993; Heyman et al., 1989a; Rothman and Xu, 2004; Su et al., 1998; Vaught and Takemori, 1979).

There are three important implications of these findings. First, these results illustrate the general principle that drug interactions can vary as a function of the endpoint under investigation. Drug interactions may be superadditive on some endpoints, additive on others, and subadditive or antagonistic on yet other endpoints. Second, this general principle suggests that drug interactions could be exploited to selectively enhance clinically desirable drug effects without enhancing (or even attenuating) untoward effects characteristic of the component drugs. Lastly, in the specific case of mu/delta opioid interactions, these results suggest that combined activation of mu and delta opioid receptors may produce effective analgesia with fewer side effects than selective activation of either mu or delta opioid receptors alone.

\subsection{Interactions between fentanyl and either MSF61 or naltrindole}

Although mu/delta antinociceptive synergy may have therapeutic benefits, the degree of delta receptor efficacy required for these interactions has not been systematically examined. To address this issue, the present study employed the compound MSF61 as an intermediateefficacy delta receptor ligand. However, despite its partial agonist effects in vitro (Furness et 
al., 2000), MSF61 did not have sufficient delta efficacy to produce a delta agonist-induced suppression of response rates in the assay of schedule-controlled responding in rhesus monkeys. Rather, consistent with its characterization as a selective delta ligand with lower efficacy at delta receptors than SNC80, MSF61 antagonized the effects of SNC80. This finding was important not only for clarifying the relative efficacy of MSF61 in comparison to SNC80 in vivo, but also for demonstrating that MSF61 doses used in this study occupied pharmacologically relevant populations of delta receptors in vivo.

The antagonist effects MSF61 in the assay of schedule-controlled responding did not necessarily preclude it from producing agonist effects on other endpoints, such as enhancement of mu agonist-induced antinociception. It is well established that different endpoints have different efficacy requirements for the production of pharmacological effects, and as a result, a given intermediate-efficacy drug can simultaneously function as an agonist on some endpoints and as an antagonist on others (e.g. (Morgan et al., 1999; Ruffolo, 1982; Walker et al., 1993). However, the results of the present study suggest that MSF61 also did not have sufficient efficacy at delta receptors to enhance fentanyl-induced antinociception. The failure of MSF61 to produce synergistic mu/delta antinociceptive interactions sets a lower limit to the delta receptor efficacy required to produce these interactions. It remains possible that compounds with higher but still submaximal efficacy (i.e. ligands with efficacy less than $100 \%$ but greater than $38 \%$ relative to SNC80) may still be capable of producing mu/delta antinociceptive synergy. For example, as noted above, the peptidic delta agonist DPDPE has efficacy at delta receptors slightly greater than that of MSF61, and it has been shown to produce antinociceptive synergy in combination with some mu agonists in rodents (Adams et al., 1993; Heyman et al., 1989a; Vaught and Takemori, 1979).

It should be stressed that the antagonist profile of MSF61 in the present in vivo studies is not necessarily inconsistent with the partial agonist profile of MSF61 in an in vitro functional assay. Although MSF61 functioned as a partial agonist in an in vitro assay of ligand-stimulated GTPgS binding, it is not uncommon for drugs with partial agonist activity in such in vitro assays to function as antagonists in vivo, presumably because they do not have sufficient efficacy to produce threshold levels of receptor activation required for production of a measurable agonist effect. As one example, low efficacy mu opioid agonists such as nalbuphine may also produce partial agonist effects in in vitro assays of GTPgS binding but produce mu antagonist effects under a wide range of conditions in vivo (Emmerson et al., 1996; Gerak et al., 1994).

The delta antagonist naltrindole also failed to produce selective synergistic antinociceptive interactions in combination with fentanyl. Rather, when the highest proportion of 36:1 naltrindole/fentanyl was studied, naltrindole appeared to attenuate both the rate-decreasing and antinociceptive effects of fentanyl. This naltrindole-induced attenuation of mu agonist effects is diametrically opposite to the enhancement of fentanyl antinociception produced by delta agonists, and this raises the possibility that delta receptor ligands may produce both positive and negative modulation of mu agonist effects. However, while delta agonists selectively enhanced only fentanyl antinociception, naltrindole attenuated both the rate-decreasing and antinociceptive effects of fentanyl. In addition, the naltrindole-induced attenuation of fentanyl effects may have resulted from mu antagonism produced by high, non-selective naltrindole doses. Naltrindole displayed 93 -fold selectivity for delta vs. mu opioid receptors in binding studies using monkey brain tissue, but it bound to mu opioid receptors with nanomolar affinity (Emmerson et al., 1994). In vivo in monkeys, naltrindole was approximately 25 -fold more potent as an antagonist of delta agonists than of mu agonists, but the pA2 value for naltrindole as a mu antagonist was 5.1 (i.e. $3.6 \mathrm{mg} / \mathrm{kg}$ ) (Negus et al., 1994). In the present study, the 36:1 naltrindole/fentanyl mixture was studied up to a dose of $3.6 \mathrm{mg} / \mathrm{kg}$ naltrindole $+0.1 \mathrm{mg} / \mathrm{kg}$ fentanyl (see Figure 4). Thus, the naltrindole/fentanyl mixture with the highest proportion of 
naltrindole was studied up to doses that would be expected to produce a modest mu antagonist effect.

The dose ratios for MSF61/fentanyl and naltrindole/fentanyl mixtures tended to be less than one and less than the dose ratio for fentanyl alone. Thus, mixtures of fentanyl with MSF61 or naltrindole produced greater behavioral depression than fentanyl alone at antinociceptive doses. To our knowledge, this is the first study to report that addition of an intermediate- or low-efficacy delta opioid to a mu agonist may not only fail to produce mu/delta antinociceptive synergy, but may also increase undesirable effects relative to a potential therapeutic effect. The implications of this finding for opioid pharmacology and drug development remain to be determined. However, mu agonist/delta antagonist drugs are being developed in response to the hypothesis that delta antagonist activity may retard tolerance to mu agonist antinociceptive effects (Abdelhamid et al., 1991; Ananthan, 2006). Although attenuation of antinociceptive tolerance could be of considerable clinical value, the potential of these medications may be limited if the therapeutic index for these mu agonist/delta antagonist drugs is lower than the therapeutic index for mu agonists alone.

\subsection{Mechanisms of delta/mu interactions}

The present study was designed primarily to assess pharmacologic determinants of mu/delta interactions in rhesus monkeys, and a main finding was that relatively high delta receptor efficacy appears to be required for mu/delta antinociceptive synergy. The neuronal mechanisms that underlie mu/delta interactions in general, and the high efficacy requirements for mu/delta antinociceptive synergy in particular, remain to be determined. However, results of the present and previous studies (Stevenson et al., 2005; Stevenson et al., 2003) in rhesus monkeys have provided the basis for several speculative comments. First, we have argued previously that the behavioral selectivity of $\mathrm{mu} / \mathrm{delta}$ interactions suggests a neuroanatomical selectivity in the substrates that mediates those interactions. Specifically, substrates capable of mediating synergistic mu/delta interactions appear to exist in neural systems underlying opioid-induced antinociception, but not in neural systems underlying opioid-induced decreases in schedulecontrolled responding for food reinforcement. The present results with SNC243A and fentanyl provide further support for the behavioral, and by extension the neuronal, specificity of mu/ delta interactions.

Second, the results of the present study suggest that high delta-receptor efficacy is required for $\mathrm{mu} / \mathrm{delta}$ antinociceptive synergy. This apparent requirement for high delta efficacy may be related to the observation that, under basal conditions, most delta receptors appear to be sequestered in cytoplasm and unavailable for occupation by exogenous ligands (Zhang et al., 1998). Insertion of delta receptors into neuronal plasma membranes can be promoted by events such as inflammation (Cahill et al., 2003; Patwardhan et al., 2005), and we have reported previously that inflammation also enhances the antinociceptive effects of delta agonists in rhesus monkeys (Brandt et al., 2001). These findings raise the possibility that inflammatory states might increase delta receptor availability, reduce efficacy requirements for production of delta receptor-mediated effects, and enable mu/delta antinociceptive synergy with lower efficacy delta ligands.

Finally, one potential substrate for mu/delta interactions could be receptors that are physically coupled into mu/delta heterodimers (Jordan et al., 2000). However, our data do not support a role for these mu/delta dimers in mu/delta antinociceptive synergy in rhesus monkeys. For example, synergistic mu/delta interactions presumably mediated by these dimers could be obtained in vitro with some delta antagonists, but not with SNC80 (Gomes et al., 2000). Conversely, our studies in rhesus monkeys have reported mu/delta antinociceptive synergy with the delta agonists SNC80 and SNC243A, but not with the delta antagonist naltrindole. 


\section{Acknowledgements}

This work was supported by Grant RO1-DA11460 from the National Institute on Drug Abuse, National Institutes of Health. A portion of this work was also supported by the Intramural Research Programs of the National Institute on Drug Abuse and the National Institute on Alcohol Abuse and Alcoholism. The authors would like to thank Joe Pocher, D.V.M., for expert veterinary assistance.

\section{References}

Abdelhamid EE, Sultana M, Portoghese PS, Takemori AE. Selective blockage of delta opioid receptors prevents the development of morphine tolerance and dependence in mice. J Pharmacol Exp Ther 1991;258:299-303. [PubMed: 1649297]

Adams JU, Tallarida RJ, Geller EB, Adler MW. Isobolographic superadditivity between delta and mu opioid agonists in the rat depends on the ratio of compounds, the mu agonist and the analgesic assay used. J Pharmacol Exp Ther 1993;266:1261-1267. [PubMed: 8396630]

Ananthan S. Opioid ligands with mixed mu/delta opioid receptor interactions: an emerging approach to novel analgesics. Aaps J 2006;8:E118-125. [PubMed: 16584118]

Brandt MR, Furness MS, Mello NK, Rice KC, Negus SS. Antinociceptive effects of delta-opioid agonists in Rhesus monkeys: effects on chemically induced thermal hypersensitivity. J Pharmacol Exp Ther 2001;296:939-946. [PubMed: 11181927]

Cahill CM, Morinville A, Hoffert C, O'Donnell D, Beaudet A. Up-regulation and trafficking of delta opioid receptor in a model of chronic inflammation: implications for pain control. Pain 2003;101:199_ 208. [PubMed: 12507715]

Calderon SN, Rice KC, Rothman RB, Porreca F, Flippen-Anderson JL, Kayakiri H, Xu H, Becketts K, Smith LE, Bilsky EJ, Davis P, Horvath R. Probes for narcotic receptor mediated phenomena. 23. Synthesis, opioid receptor binding, and bioassay of the highly selective delta agonist (+)-4-[(alpha R)alpha-((2S,5R)-4-Allyl-2,5-dimethyl-1-piperazinyl)-3-methoxybenzyl]- N,N-diethylbenzamide (SNC 80) and related novel nonpeptide delta opioid receptor ligands. J Med Chem 1997;40:695-704. [PubMed: 9057856]

Clark MJ, Emmerson PJ, Mansour A, Akil H, Woods JH, Portoghese PS, Remmers AE, Medzihradsky F. Opioid efficacy in a C6 glioma cell line stably expressing the delta opioid receptor. J Pharmacol Exp Ther 1997;283:501-510. [PubMed: 9353363]

Danielsson I, Gasior M, Stevenson GW, Folk JE, Rice KC, Negus SS. Electroencephalographic and convulsant effects of the delta opioid agonist SNC80 in rhesus monkeys. Pharmacol Biochem Behav 2006;85:428-434. [PubMed: 17112570]

Dykstra LA, Bertalmio AJ, Woods JH. Discriminative and analgesic effects of mu and kappa opioids: in vivo pA2 analysis. Psychopharmacol Ser 1988;4:107-121. [PubMed: 2899316]

Dykstra LA, Granger AL, Allen RM, Zhang X, Rice KC. Antinociceptive effects of the selective delta opioid agonist SNC80 alone and in combination with mu opioids in the squirrel monkey titration procedure. Psychopharmacology (Berl) 2002;163:420-429. [PubMed: 12373443]

Emmerson PJ, Clark MJ, Mansour A, Akil H, Woods JH, Medzihradsky F. Characterization of opioid agonist efficacy in a C6 glioma cell line expressing the mu opioid receptor. J Pharmacol Exp Ther 1996;278:1121-1127. [PubMed: 8819494]

Emmerson PJ, Liu MR, Woods JH, Medzihradsky F. Binding affinity and selectivity of opioids at mu, delta and kappa receptors in monkey brain membranes. J Pharmacol Exp Ther 1994;271:1630-1637. [PubMed: 7996478]

Furness MS, Zhang X, Coop A, Jacobson AE, Rothman RB, Dersch CM, Xu H, Porreca F, Rice KC. Probes for narcotic receptor-mediated phenomena. 27. Synthesis and pharmacological evaluation of selective delta-opioid receptor agonists from 4-[(alphaR)-alpha-(2S,5R)-4-substituted-2, 5dimethyl-1-piperazinyl-3-methoxybenzyl]-N,N-diethylbenzamides and their enantiomers. J Med Chem 2000;43:3193-3196. [PubMed: 10956228]

Gerak LR, Butelman ER, Woods JH, France CP. Antinociceptive and respiratory effects of nalbuphine in rhesus monkeys. J Pharmacol Exp Ther 1994;271:993-999. [PubMed: 7965822]

Gutstein, H.; Akil, H. Opioid analgesics. In: Brunton, L.; Lazo, J.; Parker, K., editors. The Pharmacological Basis of Therapeutics. McGraw-Hill; New York: 2005. p. 547-590. 
Heyman JS, Jiang Q, Rothman RB, Mosberg HI, Porreca F. Modulation of mu-mediated antinociception by delta agonists: characterization with antagonists. Eur J Pharmacol 1989a;169:43-52. [PubMed: 2557223]

Heyman JS, Vaught JL, Mosberg HI, Haaseth RC, Porreca F. Modulation of mu-mediated antinociception by delta agonists in the mouse: selective potentiation of morphine and normorphine by [D-Pen2,DPen5] enkephalin. Eur J Pharmacol 1989b;165:1-10. [PubMed: 2548877]

Jordan BA, Cvejic S, Devi LA. Opioids and their complicated receptor complexes. Neuropsychopharmacology 2000;23:S5-S18. [PubMed: 11008063]

Jutkiewicz EM, Eller EB, Folk JE, Rice KC, Traynor JR, Woods JH. Delta-opioid agonists: differential efficacy and potency of SNC80, its 3-OH (SNC86) and 3-desoxy (SNC162) derivatives in SpragueDawley rats. J Pharmacol Exp Ther 2004;309:173-181. [PubMed: 14722329]

Jutkiewicz EM, Walker NP, Folk JE, Rice KC, Portoghese PS, Woods JH, Traynor JR. Comparison of peptidic and nonpeptidic delta-opioid agonists on guanosine 5'-O-(3-[35S]thio)triphosphate ([35S] GTPgammaS) binding in brain slices from Sprague-Dawley rats. J Pharmacol Exp Ther 2005;312:1314-1320. [PubMed: 15574687]

Kieffer BL. Recent advances in molecular recognition and signal transduction of active peptides: receptors for opioid peptides. Cell Mol Neurobiol 1995;15:615-635. [PubMed: 8719033]

Lord JA, Waterfield AA, Hughes J, Kosterlitz HW. Endogenous opioid peptides: multiple agonists and receptors. Nature 1977;267:495-499. [PubMed: 195217]

Martin WR, Eades CG, Thompson JA, Huppler RE, Gilbert PE. The effects of morphine- and nalorphinelike drugs in the nondependent and morphine-dependent chronic spinal dog. J Pharmacol Exp Ther 1976;197:517-532. [PubMed: 945347]

Morgan D, Cook CD, Picker MJ. Sensitivity to the discriminative stimulus and antinociceptive effects of mu opioids: role of strain of rat, stimulus intensity, and intrinsic efficacy at the mu opioid receptor. J Pharmacol Exp Ther 1999;289:965-975. [PubMed: 10215676]

Negus SS. Sex and gonadal steroid hormone levels as determinants of opioid antinociception in rhesus monkeys. NIDA Res Mono 2002;182:20-22.

Negus SS, Burke TF, Medzihradsky F, Woods JH. Effects of opioid agonists selective for mu, kappa and delta opioid receptors on schedule-controlled responding in rhesus monkeys: antagonism by quadazocine. J Pharmacol Exp Ther 1993;267:896-903. [PubMed: 8246165]

Negus SS, Butelman ER, Chang KJ, DeCosta B, Winger G, Woods JH. Behavioral effects of the systemically active delta opioid agonist BW373U86 in rhesus monkeys. J Pharmacol Exp Ther 1994;270:1025-1034. [PubMed: 7932149]

Negus SS, Gatch MB, Mello NK. Effects of mu opioid agonists alone and in combination with cocaine and D-amphetamine in rhesus monkeys trained to discriminate cocaine. Neuropsychopharmacology 1998a;18:325-338. [PubMed: 9536446]

Negus SS, Gatch MB, Mello NK, Zhang X, Rice K. Behavioral effects of the delta-selective opioid agonist SNC80 and related compounds in rhesus monkeys. J Pharmacol Exp Ther 1998b;286:362-375. [PubMed: 9655881]

Negus SS, Schrode KA, Stevenson GW. Mu/kappa opioid interactions in rhesus monkeys: Implications for analgesia and abuse liability. Exp Clin Psychopharmacol. 2008in press

Patwardhan AM, Berg KA, Akopain AN, Jeske NA, Gamper N, Clarke WP, Hargreaves KM. Bradykinininduced functional competence and trafficking of the delta-opioid receptor in trigeminal nociceptors. J Neurosci 2005;25:8825-8832. [PubMed: 16192372]

Portoghese PS, Sultana M, Takemori AE. Naltrindole: A highly selective and potent non-peptide $\partial$ opioidreceptor antagonist. Eur J Pharmacol 1988;146:185-186. [PubMed: 2832195]

Rothman, RB.; Xu, H. Mu-Delta Interactions In Vitro and In Vivo. In: Chang, KJ.; Porecca, F.; Woods, JH., editors. The Delta Receptor. Marcel Dekker; New York: 2004. p. 373-400.

Ruffolo RR Jr. Review important concepts of receptor theory. J Auton Pharmacol 1982;2:277-295. [PubMed: 7161296]

Stevenson GW, Folk JE, Rice KC, Negus SS. Interactions between delta and mu opioid agonists in assays of schedule-controlled responding, thermal nociception, drug self-administration, and drug versus food choice in rhesus monkeys: studies with SNC80 [(+)-4-[(\{alpha $\}$ R)-\{alpha $\}-((2 \mathrm{~S}, 5 \mathrm{R})-4-$ 
Allyl-2,5-dimethyl-1-piperazinyl)-3-methoxybenzyl]-N,N-diethylbenzamide] and heroin. J Pharmacol Exp Ther 2005;314:221-231. [PubMed: 15792997]

Stevenson GW, Linsenmayer DC, Folk JE, Rice KC, Negus SS. Opioid interactions in rhesus monkeys: effects of delta + mu and delta + kappa agonists on schedule-controlled responding and thermal nociceptionn. J Pharmacol Exp Ther 2003;307:1054-1064. [PubMed: 14557380]

Su YF, McNutt RW, Chang KJ. Delta-opioid ligands reverse alfentanil-induced respiratory depression but not antinociception. J Pharmacol Exp Ther 1998;287:815-823. [PubMed: 9864259]

Tallarida, RJ. Drug synergism and dose-effect data analysis. Chapman and Hall/CRC; Boca Raton, FL: 2000.

Vaught JL, Takemori AE. Differential effects of leucine and methionine enkephalin on morphine-induced analgesia, acute tolerance and dependence. J Pharmacol Exp Ther 1979;208:86-90. [PubMed: 569699]

Walker EA, Butelman ER, Decosta BR, Woods JH. Opioid thermal antinociception in rhesus monkeys: Receptor mechanisms and temperature dependency. J Pharmacol Exp Ther 1993;267:280-286. [PubMed: 7901396]

Wessinger WD. Approaches to the study of drug interactions in behavioral pharmacology. Neurosci Biobehav Rev 1986;10:103-113. [PubMed: 3016616]

Woods JH, Young AM, Herling S. Classification of narcotics on the basis of their reinforcing, discriminative, and antagonist effects in rhesus monkeys. Fed Proc 1982;41:221-227. [PubMed: 7037459]

Woolverton, WL. Analysis of drug interactions in behavioral pharmacology. In: Thompson, T.; Dews, PB.; Barrett, JE., editors. Neurobehavioral Pharmacology. Lawrence Erlbaum Associates; Hillsdale, NJ: 1987. p. 275-302.

Zhang X, Bao L, Arvidsson U, Elde R, Hokfelt T. Localization and regulation of the delta-opioid receptor in dorsal root ganglia and spinal cord of the rat and monkey: evidence for association with the membrane of large dense-core vesicles. Neuroscience 1998;82:1225-1242. [PubMed: 9466442] 


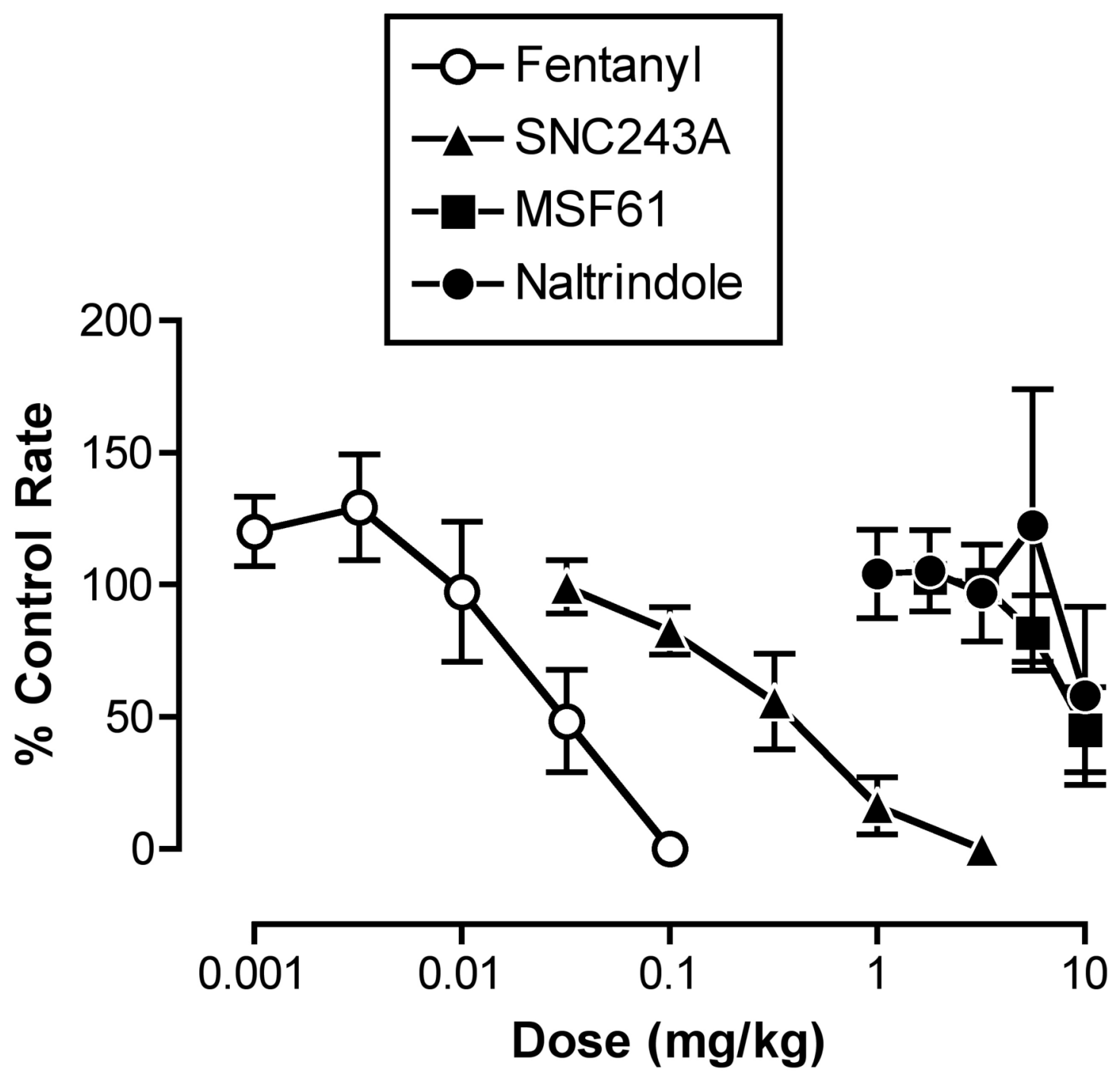

Figure 1.

Effects of the mu agonist fentanyl and the delta opioids SNC243A, MSF61 and naltrindole on rates of schedule-controlled responding. Abscissa: Dose of test drug in $\mathrm{mg} / \mathrm{kg}$ (log scale). Ordinate: Percent control rates of responding. Each point shows mean \pm S.E.M. for 5 monkeys (fentanyl, SNC243A) or 4 monkeys (MSF61, naltrindole). 

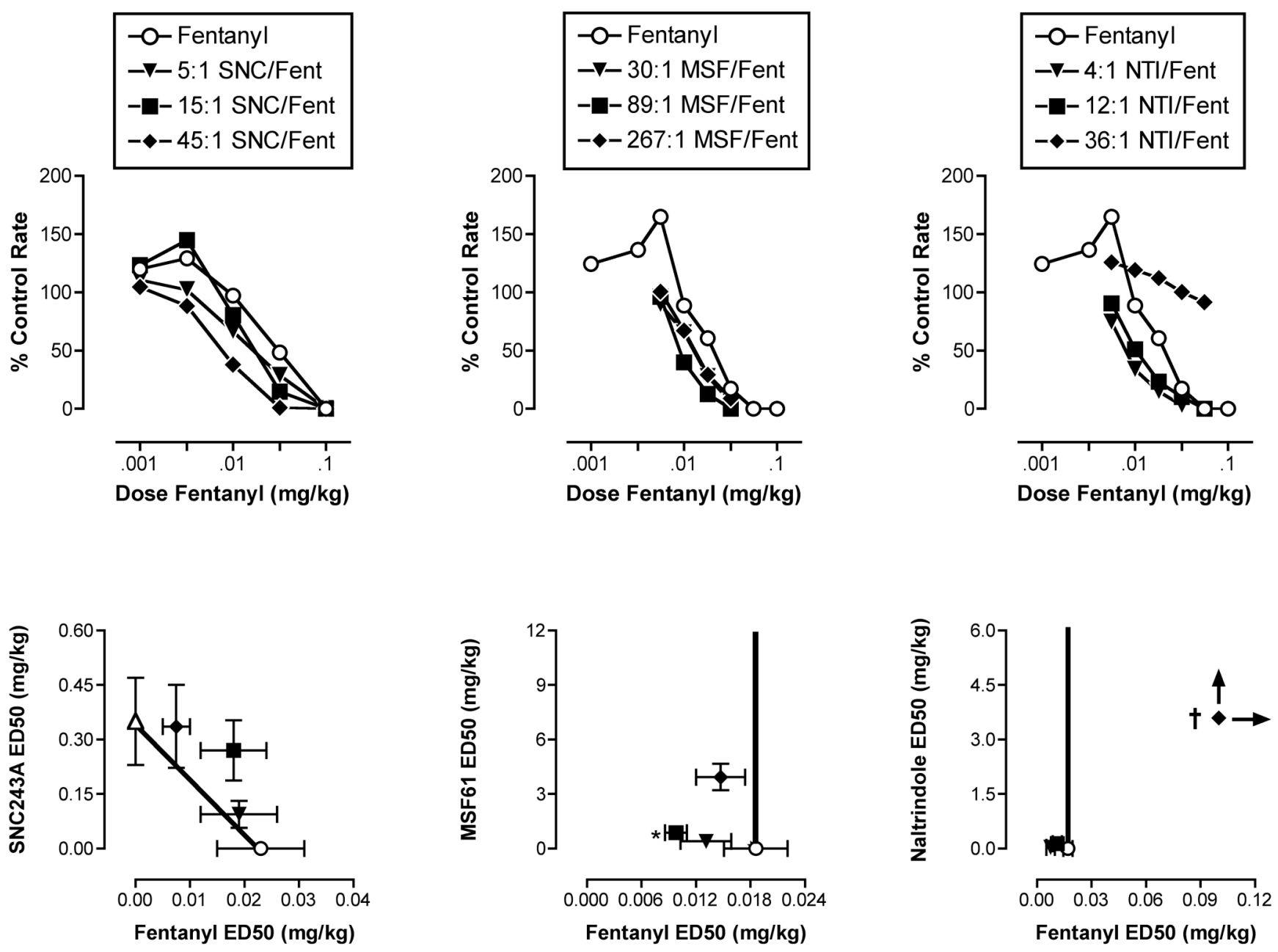

Figure 2.

Effects of fentanyl alone or in combination with different proportions of SNC243A (left panels), MSF61 (center panels) or naltrindole (right panels) in the assay of schedule-controlled responding. Top panels show dose-effect curves for fentanyl and for each mixture. Abscissae (top panels): Dose fentanyl in the mixture in $\mathrm{mg} / \mathrm{kg}$ ( $\log$ scale). The corresponding dose of the delta ligand depended on the proportion of the delta ligand in the mixture. Ordinates (top panels): Percent control rates of responding. Bottom panels show isobolograms at the ED50 effect level. Abscissae (bottom panels): ED50 values for fentanyl administered alone or in a mixture (linear scale). Ordinates (bottom panels): ED50 values for the delta ligand administered alone or in a mixture (linear scale). Each point shows mean data for 5 monkeys (left panels) or 4 monkeys (center and right panels). Error bars are not shown in the top panels for clarity. Error bars in the bottom panels show S.E.M.. * Significant superadditivity (see Table 2 ). $\dagger$ Significant subadditivity (see Table 2 ). 


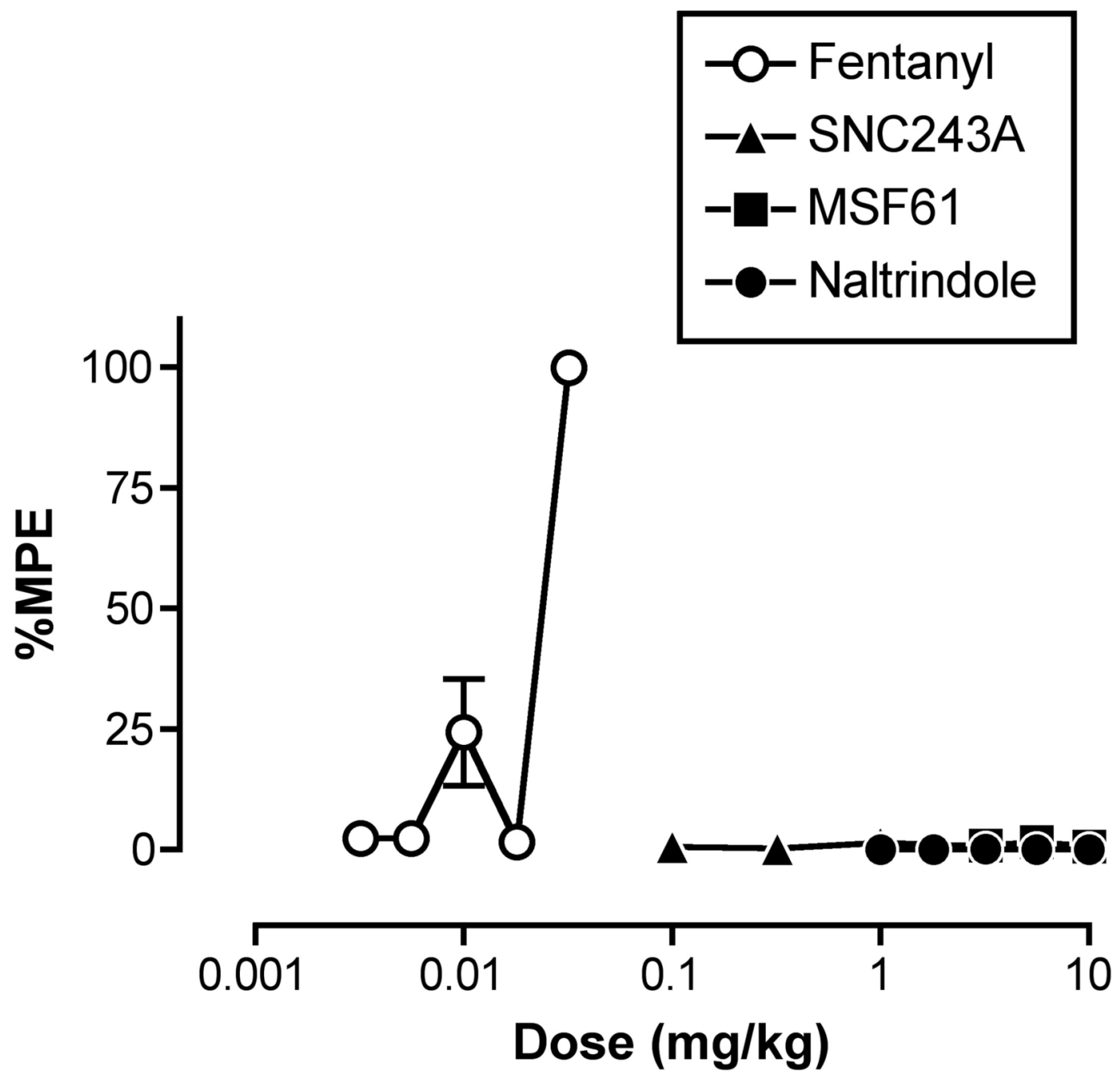

Figure 3.

Effects of the mu agonist fentanyl and the delta opioids SNC243A, MSF61 and naltrindole in the assay of thermal nociception. Abscissa: Dose of test drug in $\mathrm{mg} / \mathrm{kg}$ (log scale). Ordinate: Percent maximum possible effect (\%MPE). Each point shows mean \pm S.E.M. for 3 monkeys (SNC243A) or 4 monkeys (fentanyl, MSF61, naltrindole). 

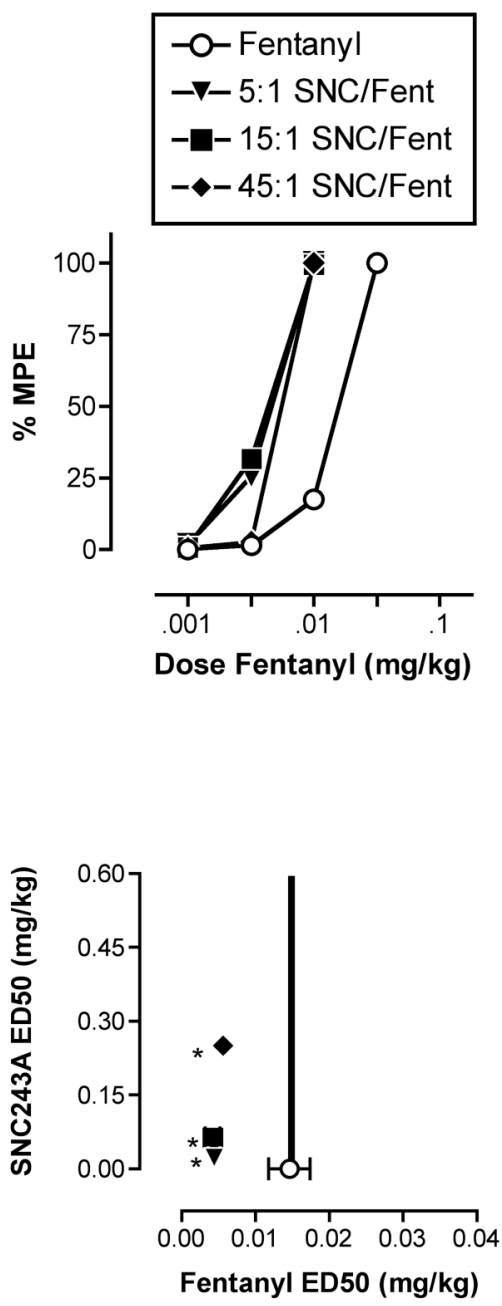
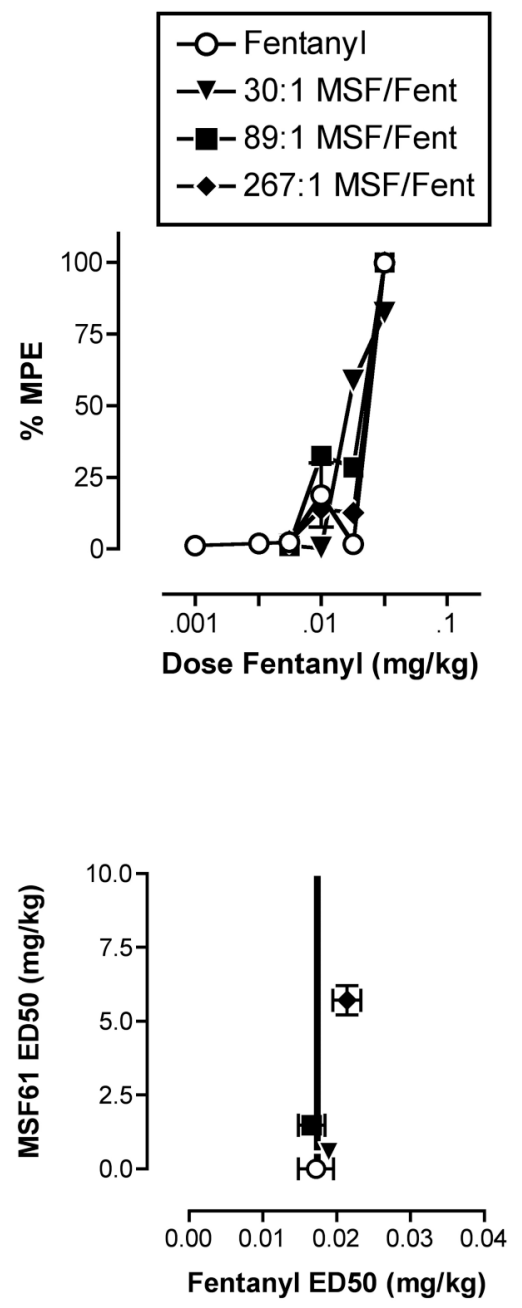
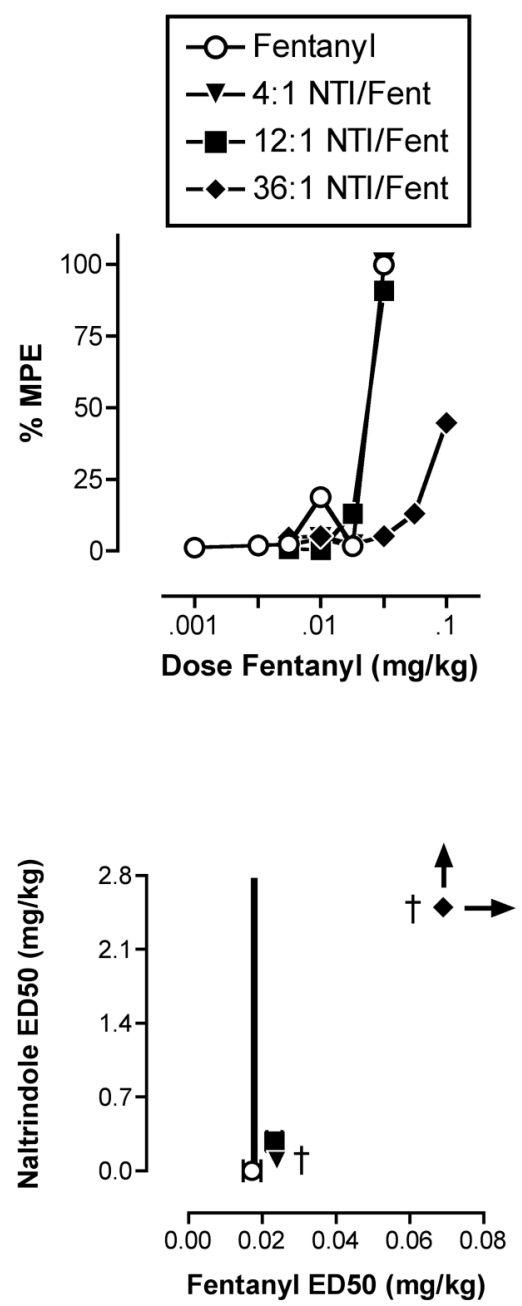

Figure 4.

Effects of fentanyl alone or in combination with different proportions of SNC243A (left panels), MSF61 (center panels) or naltrindole (right panels) in the assay of thermal nociception. Top panels show dose-effect curves for fentanyl and for each mixture. Abscissae (top panels): Dose fentanyl in the mixture in $\mathrm{mg} / \mathrm{kg}$ (log scale). The corresponding dose of the delta ligand depended on the proportion of the delta ligand in the mixture. Ordinates (top panels): Percent maximum possible effect (\%MPE). Bottom panels show isobolograms at the ED50 effect level. Abscissae (bottom panels): ED50 values for fentanyl administered alone or in a mixture (linear scale). Ordinates (bottom panels): ED50 values for the delta ligand administered alone or in a mixture (linear scale). Each point shows mean data for 3 monkeys (left panels) or 4 monkeys (center and right panels). Error bars are not shown in the top panels for clarity. Error bars in the bottom panels show S.E.M.. *Significant superadditivity (see Table 4). $†$ Significant subadditivity (see Table 4). 

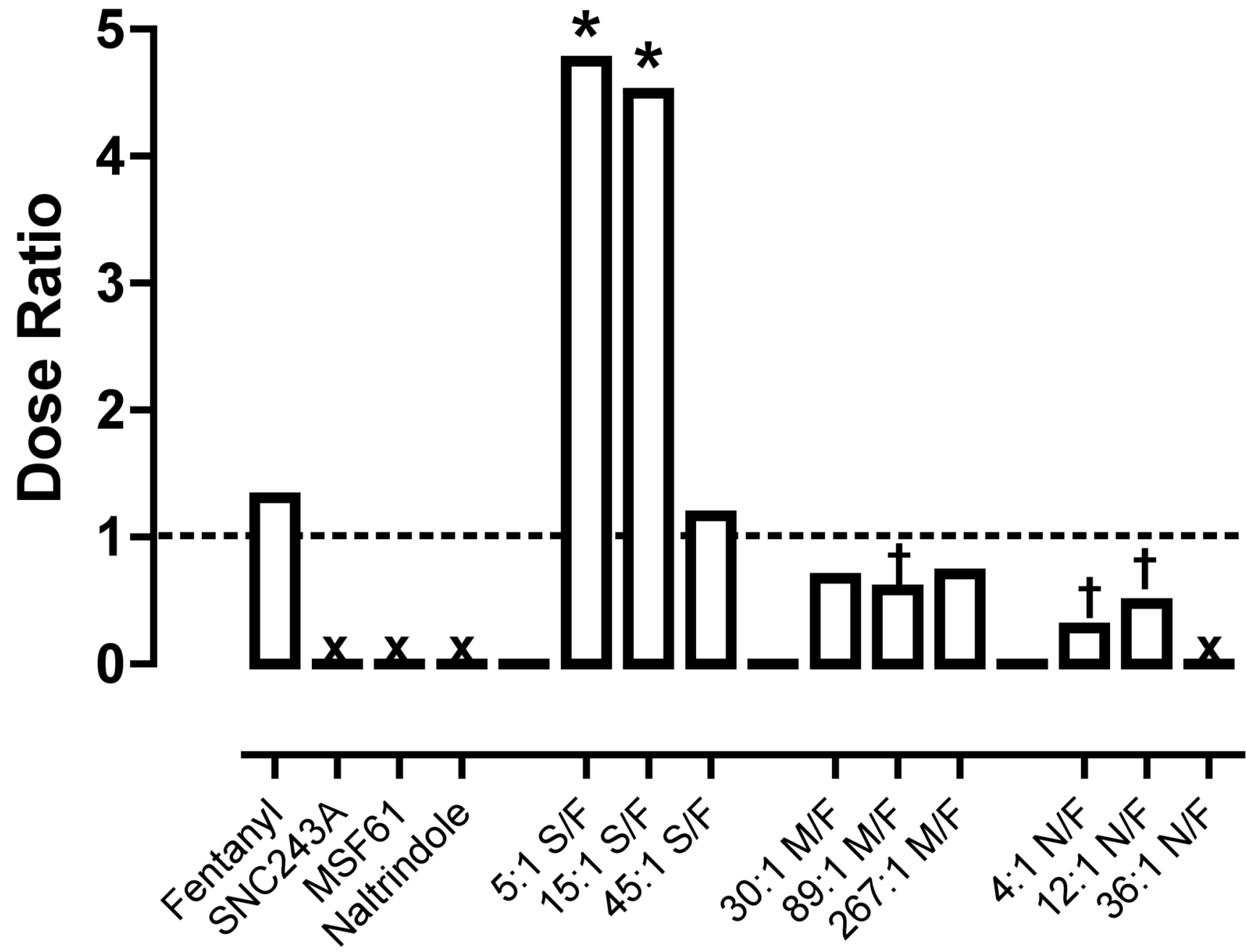

Figure 5.

Dose-ratios for each drug alone and each drug mixture for production of rate suppression and thermal nociception. Abscissa: Identity of drug or drug mixture. Ordinate: Dose ratio determined as ED50 (or Zmix) in assay of schedule-controlled responding $\div$ ED50 (or Zmix) in assay of thermal nociception. * Asterisks indicate that drug mixture was significantly more potent in the assay of thermal nociception as determined by non-overlapping confidence limits of ED50 or Zmix values (i.e. Dose Ratio $\geq 1$ ). $†$ Crosses indicate that drug mixture was significantly less potent in the assay of thermal nociception as determined by non-overlapping confidence limits (i.e. Dose Ratio <1). 
Table 1

ED50 values in $\mathrm{mg} / \mathrm{kg}$ (95\%CL) for fentanyl and a delta opioid administered alone or as part of a mixture in the assay

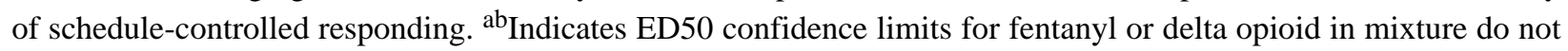

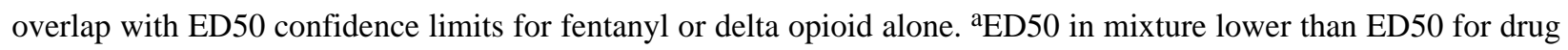
alone. ${ }^{b}$ ED50 in mixture higher than drug alone.

\begin{tabular}{|c|c|c|}
\hline Treatment & $\begin{array}{l}\text { Fentanyl } \\
\text { ED50 (95\% CL) }\end{array}$ & $\begin{array}{l}\text { Delta Opioid } \\
\text { ED50 (95\% CL) }\end{array}$ \\
\hline Fentanyl Alone & $0.023(0.012-0.045)$ & \\
\hline SNC243A Alone & & $0.35(0.18-0.68)$ \\
\hline 5:1 SNC/Fent & $0.019(0.009-0.041)$ & $0.09(0.04-0.20)$ \\
\hline 15:1 SNC/Fent & $0.018(0.010-0.033)$ & $0.27(0.15-0.49)$ \\
\hline $45: 1 \mathrm{SNC} / \mathrm{Fent}$ & $0.007(0.004-0.015)$ & $0.34(0.11-0.17)$ \\
\hline Fentanyl Alone & $0.019(0.013-0.027)$ & \\
\hline MSF61 Alone & & $>10 \mathrm{mg} / \mathrm{kg}$ \\
\hline 30:1 MSF/Fent & $0.013(0.009-0.020)$ & $0.39(0.26-0.59)^{\mathrm{a}}$ \\
\hline 89:1 MSF/Fent & $0.010(0.007-0.012)^{\mathrm{a}}$ & $0.87(0.69-1.10)^{\mathrm{a}}$ \\
\hline 267:1 MSF/Fent & $0.015(0.010-0.021)$ & $3.93(2.74-5.64)^{\mathrm{a}}$ \\
\hline Fentanyl Alone & $0.019(0.013-0.027)$ & \\
\hline Naltrindole Alone & & $>10 \mathrm{mg} / \mathrm{kg}$ \\
\hline 4:1 NTI/Fent & $0.007(0.001-0.014)$ & $0.030(0.016-0.054)^{\mathrm{a}}$ \\
\hline 12:1 NTI/Fent & $0.011(0.007-0.018)$ & $0.134(0.086-0.210)^{\mathrm{a}}$ \\
\hline 36:1 NTI/Fent & $>0.056^{\mathrm{b}}$ & $>2.0$ \\
\hline
\end{tabular}


Table 2

Predicted Zadd and experimentally determined Zmix values (95\%CL) for mixtures of fentanyl and a delta opioid in the assay of schedule-controlled responding. ${ }^{a b}$ Indicates Zmix confidence limits do not overlap with Zadd confidence limits. ${ }^{\mathrm{a} Z m i x}$ lower than Zadd (superadditivity). ${ }^{\mathrm{b}}$ Zmix higher than Zadd (subadditivity).

\begin{tabular}{|c|c|c|}
\hline Mixture & Zadd $(95 \% \mathrm{CL})$ & Zmix $(95 \% \mathrm{CL})$ \\
\hline 5:1 SNC243A/Fentanyl & $0.11(0.06-0.20)$ & $0.11(0.05-0.25)$ \\
\hline 15:1 SNC243A/Fentanyl & $0.19(0.10-0.36)$ & $0.29(0.16-0.53)$ \\
\hline 45:1 SNC243A/Fentanyl & $0.27(0.14-0.52)$ & $0.34(0.18-0.67)$ \\
\hline 30:1 MSF61/Fentanyl & $0.58(0.40-0.84)$ & $0.41(0.27-0.61)$ \\
\hline 89:1 MSF61/Fentanyl & $1.67(1.15-2.42)$ & $0.88(0.70-1.11)^{\mathrm{a}}$ \\
\hline 267:1 MSF61/Fentanyl & $4.96(3.42-7.19)$ & $3.95(2.75-5.67)$ \\
\hline $4: 1 \mathrm{NTI} /$ Fentanyl & $0.09(0.06-0.14)$ & $0.04(0.02-0.07)$ \\
\hline 12:1 NTI/Fentanyl & $0.24(0.17-0.35)$ & $0.15(0.09-0.23)$ \\
\hline 36:1 NTI/Fentanyl & $0.69(0.47-1.0)$ & $>2.1^{b}$ \\
\hline
\end{tabular}




\section{Table 3}

ED50 values in $\mathrm{mg} / \mathrm{kg}$ (95\%CL) for fentanyl and a delta opioid administered alone or as part of a mixture in the assay of thermal nociception. ${ }^{a b}$ Indicates ED50 confidence limits for fentanyl or delta opioid in mixture do not overlap with ED50 confidence limits for fentanyl or delta opioid alone. ${ }^{a}$ ED50 in mixture lower than ED50 for drug alone. ${ }^{b}$ ED50 in mixture higher than drug alone.

\begin{tabular}{|c|c|c|}
\hline Treatment & $\begin{array}{l}\text { Fentanyl } \\
\text { ED50 }(95 \% \text { CL })\end{array}$ & $\begin{array}{l}\text { Delta Opioid } \\
\operatorname{ED50}(95 \% \mathrm{CL})\end{array}$ \\
\hline Fentanyl Alone & $0.015(0.010-0.021)^{\mathrm{a}}$ & \\
\hline SNC243A Alone & & Inactive \\
\hline $5: 1 \mathrm{SNC} / \mathrm{Fent}$ & $0.004(0.003-0.006)^{\mathrm{a}}$ & $0.022(0.015-0.032)^{a}$ \\
\hline 15:1 SNC/Fent & $0.004(0.003-0.007)^{a}$ & $0.063(0.040-0.100)^{\mathrm{a}}$ \\
\hline 45:1 SNC/Fent & $0.006(0.006-0.006)^{a}$ & $0.250(0.247-0.254)^{a}$ \\
\hline Fentanyl Alone & $0.017(0.013-0.023)$ & \\
\hline MSF61 Alone & & Inactive \\
\hline 30:1 MSF/Fent & $0.019(0.013-0.028)$ & $0.57(0.38-0.84)^{\mathrm{a}}$ \\
\hline 89:1 MSF/Fent & $0.017(0.013-0.021)$ & $1.48(1.19-1.83)^{\mathrm{a}}$ \\
\hline 267:1 MSF/Fent & $0.021(0.018-0.025)$ & $5.71(4.81-6.77)^{\mathrm{a}}$ \\
\hline Fentanyl Alone & $0.017(0.013-0.023)$ & \\
\hline Naltrindole Alone & & Inactive \\
\hline $4: 1 \mathrm{NTI} /$ Fent & $0.024(0.024-0.024) \dagger$ & $0.096(0.095-0.096)^{a}$ \\
\hline 12:1 NTI/Fent & $0.023(0.20-0.028)$ & $0.28(0.24-0.33)^{\mathrm{a}}$ \\
\hline 36:1 NTI/Fent & $>0.069^{\mathrm{b}}$ & $>2.49$ \\
\hline
\end{tabular}


Table 4

Predicted Zadd and experimentally determined Zmix values (95\%CL) for mixtures of fentanyl and a delta opioid in the assay of thermal nociception. ${ }^{a b}$ Indicates Zmix confidence limits do not overlap with Zadd confidence

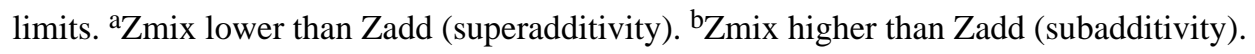

\begin{tabular}{|c|c|c|}
\hline Mixture & Zadd $(95 \% \mathrm{CL})$ & $\mathrm{Zmix}(95 \% \mathrm{CL})$ \\
\hline 5:1 SNC243A/Fentanyl & $0.088(0.060-0.128)$ & $0.026(0.018-0.038)^{a}$ \\
\hline 15:1 SNC243A/Fentanyl & $0.234(0.160-0.342)$ & $0.067(0.042-0.107)^{\mathrm{a}}$ \\
\hline 45:1 SNC243A/Fentanyl & $0.672(0.460-0.982)$ & $0.256(0.253-0.259)^{\mathrm{a}}$ \\
\hline 30:1 MSF61/Fentanyl & $0.53(0.41-0.70)$ & $0.59(0.40-0.87)$ \\
\hline 89:1 MSF61/Fentanyl & $1.54(1.18-2.03)$ & $1.49(1.21-1.85)$ \\
\hline 267:1 MSF61/Fentanyl & $4.60(3.50-6.04)$ & $5.73(4.84-6.80)$ \\
\hline 4:1 Naltrindole/Fentanyl & $0.09(0.06-0.11)$ & $0.12(0.12-0.12)^{b}$ \\
\hline 12:1 Naltrindole/Fentanyl & $0.22(0.17-0.29)$ & $0.30(0.26-0.36)$ \\
\hline 36:1 Naltrindole/Fentanyl & $0.64(0.48-0.83)$ & $>2.56 \dagger$ \\
\hline
\end{tabular}

